Terakreditasi Sinta 3 | Volume 3 | Nomor 4 (Special Issue) | Tahun 2020 | Halaman 445-454

P-ISSN 2615-725X | E-ISSN 2615-8655

http://diglosiaunmul.com/index.php/diglosia/article/view/128

\title{
TINDAK TUTUR REMAJA SEBAGAI ANAK TUNGGAL DALAM INTERAKSI SEHARI-HARI DI KELAS: KAJIAN SOSIOPRAGMATIK
}

\author{
Action of Adolescent as a Single Child in Daily Class Interactions: Sociopragmatic Study
}

\author{
Septyana Endang Herwilis Syukur ${ }^{1, *}$, Rahmat Soe'oed ${ }^{2}$, \\ dan Widyatmike Gede Mulawarman ${ }^{3}$ \\ ${ }^{1}$ Magister Pendidikan Bahasa dan Sastra Indonesia, FKIP, Universitas Mulawarman \\ ${ }^{2,3}$ FKIP Universitas Mulawarman \\ 1,*Pos-el Korespondensi: septyanaendang@gmail.com \\ 2Pos-el: rahmats@unmul.ac.id \\ ${ }^{3}$ Pos-el: widyatmike@flkip.unmul.ac.id
}

\begin{abstract}
This study aims to describe (1) the speech acts of adolescents as an only child in daily interactions in class, (2) the variety of politeness in speech acts in the language of adolescents as an only child in daily interactions in class, (3) supporting factors and speech act inbibiting factors in the speaking ability of adolescents as an only child in speaking ability. Data were collected through in-depth interviews, questionnaires, observation and documentation. The research approach is descriptive qualitative. Data validity analysis used triangulation. Data analysis techniques, namely using content analysis include data collection, data reduction, data presentation, and drawing conclusions. The results showed that first, based on the form of delivery, direct and indirect speech acts were found. In addition, based on the disclosure of meaning, it was found that literal and non-literal speech acts were found. There were many differences in speech acts performed between the main object and the object of comparison. Second, there are quite different kinds of politeness between the main object and the object of comparison. Third, the main object has two supporting factors, namely the work background of the parents and the use of language. Whereas in the inbibiting factor, the main object has two inbibiting factors, namely politeness and activity.
\end{abstract}

Keywords: speech act, the only child, variety of politeness, sociopragmatic study

\begin{abstract}
Abstrak: Penelitian ini bertujuan untuk mendeskripsikan (1) tindak tutur remaja sebagai anak tunggal dalam interaksi sehari-hari di kelas, (2) ragam kesopanan dalam tindak tutur dalam berbahasa remaja sebagai anak tunggal dalam interaksi sehari-hari di kelas, (3) faktor pendukung dan faktor penghambat tindak tutur dalam kemampuan berbicara remaja sebagai anak tunggal dalam kemampuan berbicara. Data dikumpulkan melalui wawancara mendalam, kuesioner, observasi dan dokumentasi. Pendekatan penelitian secara deskriptif kualitatif. Analisis keabsahan data menggunakan triangulasi. Teknik analisis data yakni menggunakan analisis konten meliputi pengumpulan data, reduksi data, penyajian data, dan penarikan kesimpulan. Hasil penelitian menunjukkan bahwa pertama, berdasarkan bentuk penyampaiannya ditemukan tindak tutur langsung dan tidak langsung. Selain itu, berdasarkan pengungkapan makna ditemukan tindak tutur literal dan tidak literal. Ditemukan banyak perbedaan tindak tutur yang dilakukan antarobjek utama dan objek pembanding. Kedua, terdapat perbedaan ragam kesopanan yang cukup berbeda antara objek utama dan objek pembanding. Ketiga, pada objek utama memiliki dua faktor pendukung, yaitu latar belakang pekerjaan orang tua dan penggunaan bahasa. Sedangkan pada faktor penghambat, objek utama memiliki dua faktor penghambat, yaitu kesopanan dan keaktifan.
\end{abstract}

Kata kunci: ragam kesopanan, anak tunggal, kajian sosiopragmatik 


\section{A. PENDAHULUAN}

Bahasa yang digunakan dalam komunikasi bermasyarakat adalah tuturan. Manusia menggunakan tuturan untuk menjelaskan segala sesuatu yang ingin diungkapkannya terhadap lawan tuturnya. Hal tersebut berlaku sebaliknya pada lawan tutur, yaitu dengan memberikan umpan balik terhadap penuturnya. Penggunaan tuturan dalam interaksi bermasyarakat membuat manusia memiliki ciri khas yang berbeda dengan makhluk lainnya. Bahasa juga memiliki peranan yang penting dalam menunjang keberhasilan seseorang dalam mempelajari segala bidang kehidupan, baik di kehidupan masyarakat maupun di sekolah. Oleh sebab itu, peranan pengajaran bahasa di sekolah harus mampu membantu seseorang mengenal dirinya sendiri, budayanya, budaya orang lain, mengemukakan gagasan dan perasaan untuk ikut serta dalam interaksi sehari-sehari.

Merujuk pada penelitian yang dilakukan oleh Salmani-Nodoushan (2006), penelitian tentang sebuah studi sosiopragmatik dari undangan dalam bahasa Inggris dan Persia, dapat diketahui dari hasil analisis data bahwa undangan dalam bahasa Persia sangat mengikuti norma universal yang memengaruhi menggunakan bahasa sehari-hari hingga bahasa baku. Hal ini juga menyimpulkan bahwa jenis undangan tergantung pada variabel yang telah disebutkan.

Penelitian berikutnya oleh Stukan (2018) yang melakukan penelitian tentang kegagalan sosiopragmatik, menyatakan komunikasi memiliki norma berbeda dari satu budaya dengan budaya lainnya. Maka, jika pelajar tidak diberi pengetahuan tentang perilaku linguistik di negara yang berbeda, mereka sering mengalami kesulitan berbicara dalam bahasa asing. Dalam hal ini, kegagalan sosiopragmatik terjadi. Di masing-masing jurusan sastra, ada kecenderungan untuk menjelaskan kegagalan sosiopragmatik, membandingkan bermacam-macam bahasa pada bahasa inggris. Penelitian ini menunjukkan bahwa sosiopragmatik kegagalan sering kali berujung pada gangguan komunikasi. Dengan demikian, bahasa para guru selayaknya memberikan pragmatis instruksi untuk peserta didik mereka.

Pendapat lain diungkapkan oleh (Nurlaila, 2016) yang menyatakan bahwa tuturan anak yang berusia 5 tahun 7 bulan berupa tuturan memberi perintah yang dilakukan sang anak dengan dua cara yakni, tuturan langsung dan tuturan tidak langsung. Tuturan perintah langsung yang ditemukan terdiri atas perintah biasa, perintah ajakan, perintah larangan, perintah permintaan. Sedangkan perintah tidak langsung terdiri atas perintah tidak langsung dengan modus bertanya, menolak, fakta, memuji, dan modus melibatkan orang ketiga.

Adapun penelitian lain yang berkaitan dengan tindak tutur ialah hubungan komunikasi orang tua dan anak sebagai anak tunggul dalam keluarga. dalam penelitiannya mengangkat tentang bagaimana anak tunggal tersebut berkomunikasi, yang dilakukan oleh Wardyaningrum (2013). Hasil dari penelitian tersebut menyatakan bahwa anak tunggal yang terlahir sendiri dalam melakukan tindak tutur seperti menyampaikan, memberikan saran dan berbicara dengan lawan bicaranya cenderung terbuka dan memiliki suara yang jelas namun masih dalam frekuensi yang sopan.

Penelitian lain juga menyampaikan tentang tindak tutur orang tua yang membentuk karakter anak. Hasanah (2016) dalam penelitiannya menyatakan karakter yang dibentuk oleh tindak tutur orang tua meliputi:

1. percaya diri, tenangdan dominance yang dibentuk oleh tindak tutur representatif; 
2. mandiri, tanggung jawab dan peduli sosial yang dibentuk oleh tindak tutur direktif;

3. karakter percaya diri dibentuk dengan tindak tutur yang bersifat ekspresi, rendah diri dan dendam dibentuk oleh tindak tutur yang bersifat ekspresi mengeluh, dan yang bersifat ekspresi menyalahkan;

4. karakter penakut dibentuk oleh tindak tutur komisif mengancam; dan

5. karakter pasif dibentuk oleh tindak tutur deklarasi larangan (jangan dan tidak).

Pada penelitian lain tentang tindak tutur menurut kajian pragmatik yang dilakukan oleh Ratnawati (2018), menyatakan bahwa jenis tindak tutur yang digunakan dalam tuturan guru pada pembelajaran Bahasa Indonesia, yaitu tindak tutur langsung literal dan tindak tutur langsung tak literal. Penggunaan tindak tutur bukan hanya sekedar bertanya, memerintah dan memberikan informasi. Akan tetapi, setiap tuturan guru yang muncul dalam pembelajaran Bahasa Indonesia mengandung sebuah makna. Ditinjau dari segi pragmatik ditemukan beberapa makna yang tersirat dalam tuturan guru, yaitu perintah, teguran, suruhan, pujian, peringatan, nasihat, sindiran, saran, sapaan dan klarifikasi.

Berdasarkan beberapa penelitian yang relevan terkait tindak tutur dalam kajian sosiopragmatik menunjukkan bahwa tindak tutur dipengaruhi oleh lingkungan sekitar dan pentingnya peranan orang terdekat dalam membentuk tindak tutur yang baik dalam penerapan komunikasi sehari-hari. Sehingga peneliti ingin meneliti tindak tutur yang terjadi pada anak tunggal yang memiliki latar belakang yang berbeda dengan anak yang terlahir memiliki saudara. Alasan untuk memilih anak tunggal ialah karena latar belakang yang terlahir tanpa memiliki saudara sehingga tidak ada yang mempengaruhi dalam segala tindakannya terkecuali lingkungannya dan orang- orang di sekitarnya.

Purba (2011) mengungkapkan bahwa tindak tutur serta peristiwa tutur merupakan dua gejala yang terdapat pada suatu proses komunikasi dalam menyampaikan suatu maksud dari penutur. Peristiwa tutur merupakan gejala kemasyarakatan, sedangkan tindak tutur merupakan gejala individu, dan keberlangsungannya ditentukan oleh kemampuan berbahasa penutur dalam menghadapi situasi tertentu (Chaer \& Leonie, 2010). Pada penelitian ini peristiwa tutur yang ingin diteliti adalah bentuk pemahaman bahasa penutur, sedangkan tindak tutur yang ingin diteliti adalah anak, dan berlangsungnya ditentukan oleh kemampuan berbahasa.

Penelitian ini merujuk pada beberapa aspek, yaitu pertama, tindak tutur seperti apa yang dilakukan anak tunggal dalam interaksi sehari-hari di kelas (berdasarkan hasil pengamatan awal objek lebih banyak melakukan tindak tutur perlokusi). Kedua, ragam kesantunan dalam tindak tutur berbahasa remaja anak tunggal pada interaksi seharihari (bermaksud pada bagaimana objek menyampaikan tuturannya kepada lawan bicara). Ketiga, faktor apa saja yang menghambat dan mendukung tindak tutur yang dilakukan anak tunggal dalam interaksi sehari-hari (faktor yang paling besar dalam pembentukan karakter bertutur dalam interaksi sehari-hari).

Adapun anak tunggal yang dimaksud ialah anak remaja usia 14 tahun yang mengenyam pendidikan di SMP kelas VIII. Dari hasil pengamatan awal anak tunggal yang akan menjadi bahan penelitian memiliki keunikan dalam latar belakang, yaitu bentuk pola asuh ibu sambung, ibu sambung adalah sosok wanita pengganti ibu kandung dan tidak memiliki ikatan darah dengan objek peneliti. Perbedaan emosional yang dirasakan oleh obejak peneliti dari sosok 
ibu sambung dan ibu kandung. Selain memiliki keunikan dalam latar belakang, usia objek yang menjadi daya tarik peneliti, yaitu pada usia remaja 14 tahun atau fase remaja awal memiliki kecenderungan untuk mengetahui hal baru, serta pada usia ini, yaitu 14 tahun objek sedang mencari jati dirinya sehingga sangat mudah untuk dipengaruhi oleh lingkungan sekitarnya yang akan membentuk perilaku yang ditunjukkan dalam sehari-hari, prestasi yang dicapai, maupun tindak tutur anak tunggal ini yang membuat peneliti berkeinginan untuk meneliti lebih jauh.

Peneliti berkeinginan untuk mendalami dan melakukan penelitian lebih jauh lagi, tindak tutur seperti apa yang digunakan sehari-hari oleh objek peneliti dari hasil pola asuh ibu sambung tersebut, ragam kesantunan seperti apa yang digunakan remaja anak tunggal dalam interaksi sehari-hari dan faktor apa saja yang menghambat serta mendukung dari tindak tutur objek tersebut.

\section{B. METODE}

Penelitian ini menggunakan pendekatan penelitian kualitatif dengan metode deskriptif. Dalam penelitian kualitatif bertujuan untuk mengetahui tentang sesuatu hal secara mendalam. Maka penelitian ini, peneliti mengemukakan metode penelitian kualitatif kajian sosiopragmatik.

Fokus penelitian ini untuk mengkaji ragam kesopanan dalam berbahasa remaja sebagai anak tunggal dengan kemampuan berbicara. Penelitian ini tergolong dalam jenis etnografi, jenis penelitian ini dipilih karena prosesnya mengamati kata-kata tertulis atau lisan dari perilaku subjek yang diteliti.

Data yang ditampilkan diperoleh dengan cara menyimak langsung tuturan yang digunakan dalam kegiatan seharihari oleh anak tunggal (objek utama) dan bukan anak tunggal (objek pembanding). Pengambilan data dilakukan sebanyak 3 kali, pelaksanaan pada waktu interaksi sehari-hari dengan teman sekelasnya, wawancara langsung dengan sember data.

Peneliti akan menggunakan beberapa teknik pengumpulaan data baik pokok maupun pelengkap. Untuk teknik pengumpulan data pokok akan menggunakan wawancara sedangkan untuk teknik pengumpulan data pelengkap menggunakan metode observasi dan studi dokumentasi yang akan dilakukan di lokasi penelitian.

Teknik analisis data yang digunakan dalam penelitian ini adalah analisis interaktif. Metode analisis ini mempunyai tiga komponen analisis , yaitu reduksi data, sajian data, penarikan kesimpulan (Sugiyono, 2016).

\section{PEMBAHASAN}

1. Tindak Tutur Remaja sebagai Anak Tunggal dalam Interaksi Sehari-hari di Kelas

Penelitian mengenai tindak tutur remaja sebagai anak tunggal dalam interaksi sehari-hari di kelas berdasarkan tujuan tindak dari pandangan penutur ditemukan tindak tutur lokusi, ilokusi dan perlokusi. Berdasarkan bentuk penyampaiannya ditemukan tindak tutur langsung dan tidak langsung. Selain itu, berdasarkan pengungkapan makna ditemukan tindak tutur literal dan tidak literal. Tindak tutur tersebut dibagi dalam beberapa jenis dengan masing-masing fungsi. Berikut jenis tindak tutur pada remaja sebagai anak tunggal dalam interaksi sehari-hari di kelas.

Pada subjek utama yang berstatus sebagai anak tunggal apabila ditinjau dari kategori dan maksud tuturannya, ditemukan tindak tutur lokusi berjumlah 62 tuturan, tindak tutur lokusi didominasi bentuk berita dengan jumlah tuturan 31, kemudian disusul dengan tuturan bentuk tanya dan tuturan bentuk perintah. Pada subjek pembanding apabila ditinjau dari kategori dan maksud tuturannya, ditemukan tindak tutur lokusi berjumlah 
24 tuturan, tindak tutur lokusi didominasi bentuk berita dengan jumlah tuturan 12 , kemudian disusul dengan bentuk tuturan perintah dan bentuk tuturan tanya.

Pada subjek utama ditemukan jenis tindak tutur ilokusi sebanyak 77 tuturan, tindak tutur ilokusi didominasi oleh bentuk asertif dengan jumlah tuturan sebanyak 32, kemudian disusul dengan bentuk tuturan direktif, ekspresif, komisif, dan deklaratif. Pada subjek pembanding ditemukan jenis tindak tutur ilokusi sebanyak 31 tuturan, tindak tutur ilokusi didominasi oleh bentuk asertif dengan jumlah tuturan sebanyak 12, kemudian disusul dengan bentuk tuturan direktif, pada bentuk tuturan ekspresif dan deklaratif memiliki jumlah tuturan yang sama, dan yang paling sedikit pada bentuk tuturan komisif.

Ditinjau dari jenis tindak tutur perlokusi, pada subjek utama ditemukan jumlah tuturan sebanyak 30 tuturan. Sedangkan pada subjek pembanding ditemukan jenis tindak tutur perlokusi sebanyak 15 tuturan. Tindak tutur yang terdapat pada remaja sebagai anak tunggal dalam interaksi sehari-hari di kelas ditemukan tindak tutur yang mempunyai pengaruh untuk melakukan sesuatu, mengurangi ketegangan, membuat senang, membuat terbujuk, membuat tertarik, membuat maklum, dan membuat kesal.

Berdasarkan teknik penyampaiannya ditemukan tindak tutur langsung pada subjek utama yakni sebanyak 45 tuturan, tindak tutur langsung didominasi bentuk berita dengan jumlah tuturan 25, kemudian disusul dengan bentuk tuturan tanya dan bentuk tuturan perintah. Pada subjek pembanding ditemukan tindak tutur langsung sebanyak 22 tuturan, tindak tutur langsung didominasi bentuk berita dengan jumlah tuturan 11, kemudian disusul dengan bentuk tuturan perintah dan bentuk tuturan tanya.
Pada teknik penyampaian tak langsung, pada subjek utama ditemukan sebanyak 12 tuturan, tindak tutur tak langsung didominasi bentuk tanya dengan jumlah tuturan 8 , kemudian disusul dengan bentuk tuturan perintah dan bentuk tuturan tanya yang memiliki jumlah tuturan yang sama. Pada subjek pembanding ditemukan tindak tutur tak langsung sebanyak 2 tuturan, tindak tutur tak langsung terdapat pada bentuk berita dan tanya.

Berdasarkan interaksi makna terdapat tindak tutur literal yang ditemukan pada subjek utama yakni sebanyak 52 tuturan, tindak tutur literal didominasi bentuk tuturan berita dengan jumlah tuturan 26, kemudian disusul dengan bentuk tuturan tanya dan bentuk tuturan perintah.

Pada subjek pembanding ditemukan tindak tutur literal sebanyak 24 , tindak tutur literal didominasi bentuk tuturan berita dengan jumlah tuturan 13 , kemudian disusul dengan bentuk tuturan perintah kemudian bentuk tuturan tanya. Pada subjek utama juga ditemukan jenis tindak tutur tak literal sebanyak 2 tuturan dalam bentuk perintah, sedangkan pada subjek pembanding tidak ditemukan adanya jenis tindak tutur tak literal.

Berdasarkan temuan dari penelitian tersebut diketahui bahwa tindak tutur subjek sebagai anak tunggal dalam interaksi sehari-hari di kelas lebih aktif dari subjek pembanding, hal ini menunjukkan subjek lebih terbuka dalam mengekspresikan dirinya. Subjek sebagai anak tunggal juga aktif dalam kegiatan ekstrakurikuler, misalnya pernah mendapat juara dalam lomba kerohanian.

Temuan ini tidak sesuai dengan yang disampaikan (Gunarsa \& Gunarsa, 2008), bahwa ciri-ciri anak tunggal adalah manja, egosentris, antisosial dan karena hal tersebut menjadi tidak popular. Anak tunggal juga cenderung menutup diri, peka dan mudah cemas, menarik diri dari hubungan sosial dan terlalu 
menggantungkan diri pada orang tua mereka.

Namun temuan pada penelitian ini mendukung teori yang dikemukakan Nolen-Hoeksema, Fredrickson, Loftus, \& Wagenaar (2009) yang menyatakan bahwa anak tunggal cenderung memperoleh skor tinggi sekali dalam tes intelegensi, berprestasi di perguruan tinggi, serta berhasil menjadi nomor satu. Anak tunggal juga terbukti lebih sadar akan apa yang lebih baik dan buruk, lebih kooperatif serta lebih berhati-hati, mereka juga kurang melibatkan diri dalam jenis olah raga yang berbahaya. Penjelasannya adalah bahwa para orang tua mempunyai lebih banyak waktu dan tenaga yang dicurahkan untuk anak tunggal sehingga dapat memberikan lingkungan yang lebih kaya dan lebih merangsang. Apabila keluarga bertambah besar, para orang tua mungkin semakin kurang perhatian terhadap setiap anak. Mungkin juga anak tunggal lebih kuat mengidentifikasikan diri dengan orang tua mereka.

\section{Ragam Kesopanan dalam Tindak Tutur Berbahasa Remaja sebagai Anak Tunggal dalam Interaksi Sehari-hari di Kelas}

Hasil penelitian ini penulis jabarkan sesuai pada rumusan masalah dan fokus penelitian yaitu, Ragam Kesopanan dalam Tindak Tutur Berbahasa Remaja sebagai Anak Tunggal dalam Interaksi Sehari-hari di Kelas. Data diperoleh dengan cara observasi langsung dengan subjek penelitian. Data yang diperoleh dianalisis kemudian dikelompokkan ke dalam kategori kesopanan. Ragam kesopanan yang ditemukan dalam penelitian ini dianalisis berdasarkan fungsi tuturan yang dikemukakan oleh Austin (dalam Christiandy, 2015), yaitu permintaan maaf, terima kasih, simpati, menyatakan sikap, salam, pengharapan dan pertentangan. Pengelompokan ini bertujuan untuk memperoleh temuan dan interpretasi yang benar mengenai ragam kesopanan pada remaja sebagai anak tunggal. Berikut adalah data ragam kesopanan yang ada pada remaja sebagai anak tunggal.

Terdapat perbedaan ragam kesopanan yang cukup berbeda antara subjek utama dan subjek pembanding. Pada subjek utama cenderung menyatakan sikap meliputi marah, mengkritik, berkomentar, dan menyetujui atau mengakui. Sedangkan pada subjek pembanding cenderung rata dalam mengungkapkan permintaan maaf, menyatakan sikap dan pertentangan. Ditemukan ragam kesopanan permintaan maaf pada subjek utama yakni sebanyak 1 tuturan, sedangkan pada subjek pembanding memiliki ragam kesopanan permintaan maaf sebanyak 5 tuturan. Ragam kesopanan terima kasih pada subjek utama ditemukan sebanyak 4 tuturan, sedangkan pada subjek pembanding memiliki ragam kesopanan terima kasih sebanyak 1 tuturan. Ragam kesopanan menyatakan sikap pada subjek utama ditemukan sebanyak 22 tuturan, sedangkan pada subjek pembanding memiliki ragam kesopanan menyatakan sikap sebanyak 8 tuturan. Ragam kesopanan salam pada subjek utama ditemukan sebanyak 3 tuturan, sedangkan pada subjek pembanding memiliki ragam kesopanan salam sebanyak 2 tuturan. Ragam kesopanan pengharapan pada subjek utama ditemukan sebanyak 6 tuturan, sedangkan pada subjek pembanding tidak ditemukan ragam kesopanan pengharapan. Ragam kesopanan pertentangan pada subjek utama ditemukan sebanyak 8 tuturan, sedangkan pada subjek pembanding tidak ditemukan ragam kesopanan pertentangan.

Berdasarkan hasil penelitian diketahui adanya perbedaan ragam kesopanan antara subjek dan pembanding. Terutama dalam hal menyatakan sikap, pada subjek utama 
cenderung menyatakan sikap meliputi marah, mengkritik, berkomentar, dan menyetujui atau mengakui. Ini menunjukkan anak tunggal berada pada posisi yang unik dalam hal daya saing, mereka tidak bersaing dengan saudarasaudaranya untuk mendapatkan perhatian, namun terhadap ayah dan ibunya.

Menurut Alder, anak tunggal sering membentuk rasa superioritas yang tinggi dan konsep diri yang besar. Alder menyatakan bahwa anak tunggal bias saja kurang memilih sifat kerja sama dan minat sosial, bersikap parasit, serta mengharapkan orang lain untuk memanjatkan dan melindungi mereka (Feist \& Feist, 2010).

Temuan ini sejalan dengan yang dijelaskan Walgito (2010) anak tunggal biasanya egoistis, mencari penghargaan diri dengan berlebihan, memiliki keinginan berkuasa berlebih-lebihan, mudah dihinggapi perasaan rendah diri, sikap infantilisasi yang menyatakan dirinya dalam cetusan amarah yang bukan-bukan, namun di pihak lain anak tunggal lebih mudah mengorientasikan dirinya kepada pandangan orang dewasa dan kepada cita-cita dan sikap pandangan orang dewasa. Meski tidak secara menyeluruh, secara pribadi penulis berpendapat teori ini cukup relevan jika dibandingkan dengan subjek utama penelitian, hal ini juga dipengaruhi usia subjek yang masih tergolong muda.

Segi positif, anak tunggal memiliki keterampilan serta kemampuan besar untuk melakukan perubahan dan perbaikan terhadap sesuatu keadaan (mega movers and shakers). Berorientasi pada tugas, cenderung menjadi orang yang berdisiplin, sangat bertanggung jawab, dan dapat diandalkan. Menyukai fakta, ide, dan informasi yang detail. Merasa terpanggil untuk melakukan sesuatu sebagai tantangan dengan penuh tanggung jawab. Segi negatif, kebanyakan anak tunggal sulit dikendalikan, terutama secara fisik. Mereka bukan orang-orang pemaaf, sangat menuntut hal terbaik dalam segala hal. Tidak suka mengaku bersalah, dan umumnya kurang bisa menerima kritik orang lain secara positif. Mereka terkesan lembut, dan memang termasuk orang yang mudah tersinggung perasaannya.

\section{Faktor Pendukung dan Faktor Penghambat Tindak Tutur dalam Kemampuan Bertutur Remaja sebagai Anak Tunggal \\ Data mengenai latar belakang} pekerjaan orang tua diperoleh dari teknik wawancara langsung dengan subjek penelitian. Berdasarkan hasil penelitian diperoleh informasi bahwa subjek utama diasuh oleh seorang ibu tunggal dan merupakan ibu sambung. Sedangkan subjek pembanding memiliki orang tua yang lengkap dan keduanya bekerja. Ibu dari subjek pembanding merupakan seorang Pegawai Negeri Sipil.

Data tingkat kesopanan diperoleh dari observasi langsung dengan subjek penelitian. Pada subjek utama, yaitu dapat menempatkan diri ia harus menuturkan sebuah kalimat. Ada pun perbedaan tuturan subjek utama, yaitu dengan adanya penggunaan bahasa daerah jika berada pada lingkungan rumah, sedangkan di luar lingkungan subjek utama lebih memilih menggunakan bahasa informal terhadap temannya yang terkadang terdengar kasar untuk di kalangan orang dewasa, namun tuturan pada orang dewasa subjek utama memiliki tuturan yang cukup sopan. Kesopanan pada subjek pembanding memiliki tuturan yang baik pada semua orang, tanpa memandang dari mana kalangan lawan tuturnya. Hanya saja subjek pembanding lebih menggunakan bahasa informal dalam tindak tutur sehari-hari dengan lawan tutur yang memiliki usia yang sama dengan subjek pembanding, namun tidak melanggar tentang kesopanan dalam tindak tutur. 
Sedangkan ukuran keaktifan diperoleh dari teknik wawancara langsung dan observasi langsung dengan subjek penelitian. Berdasarkan hasil penelitian dapat diperoleh informasi bahwa subjek utama dapat diasumsikan sebagai anak yang aktif di kelas maupun di luar kelas. Berbeda dengan subjek utama, subjek pembanding dalam penelitian ini dapat diasumsikan kurang aktif di kelas maupun di luar kelas.

Penggunaan bahasa pada subjek pembanding dengan subjek utama cenderung memiliki kesamaan pada penggunaan bahasa, yaitu campuran. Hal ini dipengaruhi karena latar belakang lingkungan tempat tinggal subjek penelitian adalah kawasan yang cenderung homogen dengan didominasi suku Buton.

Berdasarkan hasil penelitian diketahui subjek utama memiliki dua faktor penghambat dalam kemampuan bertutur, yaitu latar belakang pekerjaan orang tua dan penggunaan bahasa. Kedua faktor ini saling berkorelasi, subjek diasuh oleh ibu tunggal sehingga intensitas berkomunikasi jarang dilakukan dan penggunaan bahasa sehari-hari di rumah dengan ibunya adalah bahasa daerah.

Sebagaimana yang diungkapkan (Sari et al., 2018) bahwa beberapa tantangan muncul yang pasti dihadapi anak tunggal, yaitu kesulitan hubungan pada orang tua dan anak, jika orang tua memberikan tekanan atau harapanharapan kepada anak tunggal. Kemudian tantangan lain adalah menjadi penyokong orang tua satu-satunya di kemudian hari baik secara emosional maupun finansial. Tantangan berikutnya adalah kemampuan untuk mengatasi konflik terhadap teman sebayanya, kesulitan ini dipercaya karena kekurangan kesempatan untuk merasakan konflik dengan saudara.

Sedangkan faktor pendukung dalam kemampuan bertuturnya adalah keaktifan dan kesopanan. Pada temuan penelitian dapat dilihat bahwa tidak hanya aktif di kelas, subjek juga aktif mengikuti kegiatan di luar sekolah. Hal ini juga tidak sejalan dengan teori yang dikemukakan Hurlock (dalam Gunarsa, 2011), bahwa ciri-ciri anak tunggal adalah manja, antisosial dan karena hal tersebut menjadi tidak popular. Anak tunggal juga cenderung menutup diri, peka dan mudah cemas, menarik diri dari hubungan sosial dan terlalu menggantungkan diri pada orang tua mereka. Sebab pada subjek penelitian cenderung sebaliknya.

\section{PENUTUP}

Tindak tutur remaja sebagai anak tunggal dalam interaksi sehari-hari di kelas: kajian sosiopragmatik berdasarkan tujuan tindak dari pandangan penutur ditemukan tindak tutur lokusi antara subjek dan pembanding memiliki perbandingan jenis tuturan, ilokusi, dan perlokusi. Sedangkan berdasarkan bentuk penyampaiannya ditemukan perbedaan pada tindak tutur langsung dan tidak langsung. Selain itu, berdasarkan pengungkapan makna ditemukan tindak tutur literal dan tidak literal. Ditemukan banyak perbedaan tindak tutur yang dilakukan antarsubjek utama dan subjek pembanding. Seorang remaja anak tunggal memiliki banyak perbedaan dalam penyampaian tuturan sehari-hari, banyak faktor yang membentuk tindak tutur seorang remaja anak tunggal. Namun memiliki hal yang serupa dalam hal mengekspresikan diri, anak tunggal cenderung ingin lebih menonjol walaupun dengan cara mereka sendiri.

Ragam kesopanan remaja sebagai anak tunggal dalam interaksi sehari-hari di kelas: kajian sosiopragmatik ditemukan perbandingan antara subjek dan pembanding dalam ukuran permintaan maaf, ucapan terima kasih, menyatakan sikap, mengucap salam, pengharapan dan pertentangan. Terdapat perbedaan ragam kesopanan yang cukup berbeda antara subjek utama dan subjek pembanding. Pada subjek utama cenderung 
menyatakan sikap meliputi marah, mengkritik, berkomentar, dan menyetujui atau mengakui. Sedangkan pada subjek pembanding cenderung rata dalam mengungkapkan permintaan maaf, menyatakan sikap dan pertentangan.

Faktor pendukung dan faktor penghambat tindak tutur yang terdapat dalam interaksi sehari-hari pada remaja yang berstatus sebagai anak tunggal memiliki faktor masing-masing. Pada subjek utama memiliki dua faktor pendukung, yaitu jarak sekolah yang dekat dengan rumah, dan keaktifan. Sedangkan pada faktor penghambat, subjek utama memiliki dua faktor penghambat, yaitu latar belakang pekerjaan orang tua dan penggunaan bahasa. Pada subjek pembanding memiliki dua faktor pendukung dan dua faktor penghambat. Ada persamaan faktor penghambat pada subjek utama dan subjek pembanding, yaitu dalam hal penggunaan bahasa.

\section{DAFTAR PUSTAKA}

Christiandy. (2015). Analisis Tindak Tutur Kru Bus dengan Penumpang Bus Jurusan Yogyakarta-Parangtritis (Kajian Pragmatik). Journal of Chemical Information and Modeling, 53(9), 1689-1699. https://doi.org/10.1017/CBO9781 107415324.004

Feist, J., \& Feist, G. J. (2010). Teori Kepribadian. Edisi Ke-7. Jakarta: Salemba Humanika.

Gunarsa, S. D. (2011). Konseling dan Psikoterapi. Jakarta: Libri.

Gunarsa, S. D. \& Gunarsa, Y. S. D. (2008). Psikologi Perkembangan Anak dan Remaja. Jakarta: BPK Gunung Mulia.

Hasanah, U. (2016). Pola Asuh Orangtua dalam Membentuk Karakter Anak. Elementary: Jurnal Ilmiah Pendidikan Dasar, 2(2), 72-82. Retrieved from https://e-

journal.metrouniv.ac.id/index.php/e lementary/article/view/pola-asuhorangtua-dalam-membentuk-

karakter-anak

Nolen-Hoeksema, S., Fredrickson, B. L., Loftus, G. R., \& Wagenaar, W. A. (2009). Atkinson \& Hilgard's Introduction to Psychology (15 ${ }^{\text {th }}$ Edition). In Wadsworth Cengage Learning. Andover: Cengage Learning EMEA. Nurlaila, M. (2016). Pengaruh Bahasa Daerah (Ciacia) terhadap Perkembangan Bahasa Indonesia Anak Usia 2 Sampai 6 Tahun di Desa Holimombo Jaya. Retorika, 9(2), 114-119. https://doi.org/10.26858/retorika.v 9i2.3801

Purba, A. (2011). Tindak Tutur dan Peristiwa Tutur. Pena: Jurnal Pendidikan Bahasa dan Sastra, 1(1), 7792. Retrieved from https://onlinejournal.unja.ac.id/pena/article/view $/ 1426$

Ratnawati, I. I. (2018). Kajian Pragmatik Percakapan Guru dan Siswa dalam Pembelajaran Bahasa Indonesia di SMA Advent Balikpapan. Stilistika: Jurnal Babasa, Sastra, dan Pengajarannya, 3(1), 1-9. https://doi.org/10.33654/sti.v3i1.4 99

Salmani-Nodoushan, M. A. (2006). A Comparative Sociopragmatic Study of Ostensible Invitations in English and Farsi. Speech Communication, 48(8), 903-912. https://doi.org/10.1016/j.specom.2 005.12.001

Sari, S. L., Devianti, R., \& Safitri, N. (2018). Kelekatan Orangtua untuk Pembentukan Karakter Anak. Educational Guidance and Counseling Development Journal, 1(1), 16-31. https://doi.org/10.24014/egcdj.v1i 1.4947

Stukan, D. (2018). Sociopragmatic Failure: Struggling with CrossCultural Differences in Communication. Open Journal for 
Anthropological Studies, 2(1), 27-36. https://doi.org/10.32591/coas.ojas. $0201.03027 \mathrm{~s}$

Sugiyono. (2016). Metodologi Penelitian

Kuantitatif, Kualitatif, dan R\&D. Bandung: CV Alfabeta.

Walgito, B. (2010). Pengantar Psikologi Sosial. Yogyakarta: Andi.

Wardyaningrum, D. (2013). Komunikasi untuk Penyelesaian Konflik dalam Keluarga: Orientasi Percakapan dan Orientasi Kepatuhan. Jurnal AlAzhar Indonesia, 2(1), 47-58. Retrieved from https://jurnal.uai.ac.id/index.php/S $\mathrm{PS} /$ article/view/110 